\title{
Below Normal Body Height
}

National Cancer Institute

\section{Source}

National Cancer Institute. Below Normal Body Height. NCI Thesaurus. Code C78219.

Body height below the normal range. 